\title{
"Brick" rationalism architecture in the eclecticism of religious buildings, public buildings and industrial enterprises of the Taganrog city in the late 19th and early 20th centuries.
}

\author{
Alexandra Lyudmirskaya* \\ Don State Technical University, 344010, Rostov-on-Don, Russia
}

\begin{abstract}
The article analyzes the eclectic tradition in the architecture of religious buildings, public buildings and industrial enterprises of Taganrog, the peculiarities of its manifestation in the diverse stylistic palette of the city, including neo-Gothic and Art Nouveau, touches upon the specifics of the stylistic trends' manifestation in the "brick style" rationalist architecture.
\end{abstract}

\section{Introduction}

Having a unique originality, the original city of Taganiy-Rog in the water area of the Azov Sea starts its history on the initiative of Peter 1 in 1698 as a harbor and an outpost in the south of the Russian state, designed to become the trade and administrative center of the Azov region. Further more than a century of the city development led to the fact that the existing dense and integral urban planning structure was formed in the form of a quarterbeam system of streets and squares at the end of the XIX century, which is one of the best manifestations of urban planning art. And by the 1840s, Taganrog had been structurally formed within the boundaries of the general plan and acquired a certain architectural completeness and appearance, characteristic of the classicism period with an ensemble solution of important city-forming nodes characteristic of this style [1].

\section{Main part}

The main recognizable high-rise dominants were the cult buildings of Taganrog. They were a necessary compositional part of city squares, bifurcationally pulling the city streets to themselves, clearly structuring the entire planning fabric of the city, picturesquely revealing the city silhouette both from the sea and from its opposite side. This method of planning decision was a fundamental town-forming feature of the Taganrog city planning and is typical for the location of all religious buildings of the city.

\footnotetext{
* Corresponding author: a-lyudmirskaya@mail.ru
} 
Temples of the first half of the 19th century unites a common stylistic unity due to the fact that they were erected on the basis of classical compositions, had strict traditional forms. Only in the last third of the 19th century in the architectural appearance of the cult buildings of Taganrog, it became possible to observe a mixture of several stylistic motives in one project, which is typical for the late eclecticism of the late 19th and early 20th centuries. For example, the Archangel Michael Church was built in 1877 in classical style using neoRenaissance motifs at the intersection of streets leading to the station. Around the church, a light, openwork fence in the "Gothic" style was erected, part of which has survived to this day [2].

At the beginning of the 20th century, the churches of John the Baptist and Saints Peter and Paul in the Neo-Russian style, the Armenian Church in the Gregorian style were built in Taganrog, which further enriched the architectural panorama of the city, but were later demolished [3].

With the trade development, foreign nationals from Europe began to arrive in the southern lands of the Russian state. So, in Taganrog in 1860, about 900 ships moored under the flags of twenty European countries. Foreign consulates were opened in the south of Russia. Only in Taganrog there were 16 of them: Austrian, Belgian, British, Dutch, Portuguese, Spanish, Greek, etc. With the influx of foreigners to Taganrog, it became necessary to build religious buildings for the population of various confessions.

In Taganrog, as in other cities of the Don army Region, there was a Lutheran society. In 1864, it acquired a place at the corner of Nikolaevskaya Street, where a carpentry workshop was located, which was later converted into a church. The church had neo-Gothic lancet windows, separated by a thin Gothic column, turning into a four-leafed and ending with a lancet cornice, the entrance was accented with a lancet arch and crowned with a small bell tower, ending with a Gothic spire, which was flanked by small turrets-machicolation. In 1923 the church ceased to exist.

By the middle of the 19th century, 748 Jews lived in the city. From 1859 to 1876 a synagogue according to the project of the Taganrog architect M.P. Petrov was built for them. A small building was located at the intersection of the current street. Rosa Luxemburg and Turgenevsky lane and was built in eclectic motives of oriental architecture.

During the heyday of the economy and the foreign capital attraction, somewhere after 1860 , capital civil construction of public buildings for various purposes was expanding in the city. The typology of buildings for mass use is becoming more diverse: with the banking system development, banking institutions are built, transport - a railway station and a pier, trade - buildings of shops and hotels, education - buildings of specialized educational institutions, culture - entertainment buildings, industries - factories and plants, etc. In this regard, the infrastructure of the growing city is filled with new architectural and stylistic content, which is embodied in an amazing variety of buildings for various purposes, requiring a different artistic expression, reflected in the unrestrained choice of various eclectic preferences of the late eclecticism development, designed for every taste and pocket of the customer.

In 1869, a railway was built through Taganrog, since the sea harbor could not cope with the growing needs of the city, which influenced its further rapid economic and urban development and the spread of the city in the project of its expansion inland from the harbor (1863).

In 1869 , one of the first two-storey public building of the railway station was erected in the "brick" style, in the architectural appearance of which the features of the Neo-Renaissance eclecticism and neo-Romanesque architecture were reflected. Wikipedia states about the Taganrog station building: "The two-story station building was built in 1869 of red brick, without the use of plaster, with patterned masonry. Architect - S. I. Zagoskin. The station building is a typical example of red-brick eclecticism, popular in Rostov and Taganrog" [4]. 
Bourgeois capital penetrates into the economy of Russian capitalism in the south of the country, which is reflected in the formation of a demand for the construction of bank and exchange buildings, which were initially opened in rented premises of the rich mansions in Taganrog. The banking architecture of the city in this period reflects the tendencies of classicism and neo-Renaissance (the building of the City Council, the Azov-Don Bank). In the architecture of public buildings in Taganrog of this time, baroque tendencies are widespread, characterized by the expression and plasticity of this style (the building of the District Court), adjacent to strictly moderate forms of classical eclecticism.

A rare but vivid manifestation of the rationalism eclecticism in the diverse architectural palette of Taganrog is neo-Gothic, which has declared itself in the elements of style in the architecture of public buildings in the city. The influence of romantic tendencies was reflected in the architecture of the fire station building (1846), which had a high octahedral red brick tower with rows of narrow windows in the form of arches, an observation deck and a pointed end, visible in the picturesque city panorama against the background of low-rise mansion buildings.

In the second half of the XIX century the urban population growth required the construction of educational institutions, therefore, with the help of local government funds and with the help of wealthy people of the city, a network of institutions of lower and secondary vocational education is developing.

The rear of the Mariinsky Female Gymnasium (architect A. Zagoskin) is being erected as "a bright work of "red brick eclecticism". Built in 1875, it embodies the artistic taste of the Russian South at that time. Semicircular and rectangular pilasters, decorative "croutons" along the cornice, stylized rustications, a heavy parapet, huge semicircular windows were supposed to leave passers-by and visitors with a sense of the life stability and striving for beauty" [5]. The main stylistic trend in the appearance of the gymnasium was the calm and balanced neo-Romanesque style, and in the wing, which was completed later, the features of the Art Nouveau style are clearly visible. The building of the gymnasium is of the corridor type with predominance of longitudinal walls in the design.

In 1900, a four-year female school was opened (architect B.A. Rozhnov), a three-story symmetrical structure in the plan of which was made in the classical style, and in 1901 - an eight-grade technical school (architect B.A. Rozhnov), a corner building which has a "brick" style based on the Renaissance and classical architecture. The hall-corridor structure of the central volume of the technical school was supposed to be covered by a glass dome made of metal trusses in the Art Nouveau style, but, as usually happens, there was not enough money, so the dome had to be abandoned, and the walls remained unplastered. In the school interiors, it is possible to see huge doorways under the semicircular entrances, in the structural style of the lancet "Gothic" bindings of which the influence of the new Art Nouveau style can also be traced.

For the eight-grade commercial school in Taganrog, opened in 1910, a special two-story red-brick building was built, which had an appropriate layout and was distinguished by its architectural appearance simplicity. The building had a classic three-part symmetrical structure, it was erected indented from the red line. The school territory had a fence with stone pillars and a metal lattice based on plant motifs of the Art Nouveau style.

In 1916, in Taganrog, a red-brick building of the second women's gymnasium (now a radio engineering institute (architect A.M. Ginzburg), similar to the University of Athens) was built in the neoclassical style, using the forms of the Palladian neo-Renaissance. Alexander Balandin, priest of the Church of the Blessed Virgin Mary Nativity at male gymnasium, described the architecture of the building in the following way: "The second female gymnasium: hexo-style - six huge, heavy red brick columns, a high and long cement portal leading to a relatively small door-vestibule. The main pediment is a huge triangle of red, undraped bricks, as if hastily folded, unstable, ready to collapse, the same and two side 
gables. All this is in great disproportion with the facade and gloomy. Venetian windows on the second floor somewhat enliven the building. The builders claim that this building exactly reproduces the University of Athens ... " [6].

One of the city's medical institutions - the Gordon sanatorium, built in the late 1880 s can be considered interesting from the point of view of artistic expressiveness of eclecticism with the use of motifs of "Moorish" architecture in the form of stylized oriental ornaments on the walls of the building and horseshoe-shaped arches of window openings [7]. However, the space-planning solution of the object has nothing to do with the eastern architecture, since the very purpose of the building has a reference to Turkish baths and hamam, in which oriental motives are already very stable.

An example of the neo-Russian stylistics use in the architecture of public buildings in Taganrog is the pharmacy R.B. Idelson (1884), in the decoration of the facades of which were used in the form of bas-reliefs, thin columns, lancet window openings, due to which the external appearance of the building may resemble the "Gothic" style [8].

At the beginning of the new century, in 1911, a post office building was erected in Taganrog (the builder was the banker A. A. Davidovich), it was also the bank house of Davidovich. The building is made in the style of Art Nouveau from yellow and gray bricks. Unfortunately, the full-blooded appearance of the architectural heritage site, which is part of the historical building ensemble of Frunze street, which was one of the most expensive at that time, was partially lost: the leftmost door under the arch was laid, displacing the symmetry of the facade of the building, balconies with metal gratings and a parapet of the roof were knocked down during Soviet rule, attributing the appearance of the building to a new architectural style.

End of the 19th century was marked by the rapid development of industry and the construction of large industrial enterprises in the city: metallurgical, steel, boiler, ship repair, gas, iron foundry, brewery, many of which, such as boiler, metallurgical, brewery, were also built in the strict style of "brick" eclecticism.

The metallurgical plant in Taganrog was built by Belgians Count Paul de Gemptin, Ludwig Transester and Julius Gerpeny. In 1894, they began dismantling the Belgian John Kokkeril plant for its installation in Taganrog. In 1896 the plant went into operation. Various stages of the plant were gradually launched: foundry, mechanical, open-hearth shops; blast furnace, coconut, lime kilns. The plant occupied a large territory, most of its buildings were erected in the "brick" style, which was especially characteristic of the industrial architecture of that time, which most tectonically provided the large-span structural component of industrial structures. In the "brick" style, the three-storey building of the power plant, as well as the buildings of the factory hospital and the main office were built on the territory of the plant.

The "brick" style of neo-baroque is characteristic of the Taganrog brewery, the oldest in the south of Russia, which has been operating in the city since 1887.

The building of wine warehouses in Taganrog, also built in a "brick" style, has not survived to our time.

From the point of view of the Neo-Gothic influence in a complex eclectic interweaving of foreign styles, it is possible to distinguish the Taganrog tannery, operating since 1858. On its territory there were the main building, dryers, warehouses, mechanical workshops, steam heating, sea water supply, electric lighting were arranged. The factory buildings are built in the "brick" style of the neo-Renaissance, one of the buildings has a huge gallery with stainedglass neo-gothic glazing of metal frames. The plant is currently in an abandoned state and is being destroyed.

During the period of the classicism and neo-Renaissance strict eclecticism change to later trends with the inclusion of other foreign styles in the architectural eclectic palette in 186070 , the development of a "brick" style is characteristic both for many cities of the Russian 
South and for Taganrog, for which a simple and technological way achievement of facades' complex plastic expressiveness becomes the main one. On the territory of the Don army Region, more than 14 varieties of bricks with various brands were found. Several brick factories were operating in Taganrog at this time. Their number is difficult to determine, but judging by the private collection of one of the city caring residents, there were quite a few of them. The bricks were produced in various colors and sizes. Residents even found bricks from the manufactory of Mikhalkov's ancestors [9]. It is known about the production of bricks by the owner of the "Gothic" castle in the village of Zolotaya Kosa near Taganrog, A. Lakier. He produced more bricks for his own needs at his factory "Golden Economy Lakiera" (the brick has the ZEL stamp) [10], from which his unique "Gothic" castle was built, which is an example of a country villa or an estate on a high picturesque coast Gulf of Azov.

\section{Conclusion}

The production of bricks of various modifications (including figured bricks) was able to satisfy any architectural demand, and the style itself was an excellent expression of rationalism in architecture and found its application both in projects of civil public buildings, religious buildings and industrial architecture, and in mass residential development.

At the end of the 19th and beginning of the 20th centuries. in the cities of the Don Cossack Region, the traditions of eclectic architecture of "historical" styles were established. In Taganrog, in most cases, the "red brick" style of buildings in public use of citizens, including religious and industrial ones, has an extraordinary variety of architectural styles and techniques that have formed a unique tint and scale of the city with a human face.

\section{References}

1. https://sites.google.com > istoriceskijtaganrog > ulicy

2. https://taganrogprav.ru > taganrog-gorod-portikov-i-ko...

3. M.E. Grigoryan, Eclecticism in the architecture of Taganrog in the second half of the 19 th century.

4. https://ru.wikipedia.org > wiki > Taganrog_(station)

5. https://sites.google.com $>$ site $>$ cehova-ulica $>$ dom-104

6. https://ru.wikipedia.org > wiki > Building _ "A" _ TRTI

7. https://ru.wikipedia.org > wiki > Sanatorium_Gordon

8. https://ru.wikipedia.org > wiki > Pharmacy_Idelson

9. https://gre4ark.livejournal.com

10. https://brick-library.ru > kirpich-s-klejmom-zel 